\title{
AVHRR NDVI Baseline for Natural Vegetation Ecosystems in Northern Canadian National Parks
}

\author{
Yuhong $\mathrm{He}^{1 *}$, Paul Dixon ${ }^{2}$, John F. Wilmshurst ${ }^{3}$ and Xulin Guo ${ }^{4}$ \\ ${ }^{1}$ Department of Geography, University of Toronto Mississauga, 3359 Mississauga North Road, Mississauga, ON L5L 1C6, Canada \\ ${ }^{2}$ Western and Northern Service Center, Parks Canada, 145 McDermot Avenue, Winnipeg, MB, R3B 0R9, Canada \\ ${ }^{3}$ Jasper National Park of Canada, P.O. Box 10, Jasper AB TOE 1EO, Canada \\ ${ }^{4}$ Department of Geography, University of Saskatchewan, Room 110 Kirk Hall, 117 Science Place, Saskatoon SK S7N 5C8, Canada
}

\begin{abstract}
The establishment of a set of vegetation baseline values for the sub-arctic protected ecosystems would permit the identification of ecosystem change in the context of global change. A common satellite-based index, the Normalized Difference Vegetation Index (NDVI), has a long history of use and can be averaged to establish a "normal" vegetation condition in a given region for a given time. Based on an analysis of 23-year NDVI time series data derived from the Advanced Very High Resolution Radiometer (AVHRR) satellite imagery, this study investigated a simple method to establish a set of NDVI baseline for the sub-arctic natural ecosystems in the 12 Canadian northern National Parks. The key result of this study is that a set of annual and monthly NDVI baseline for each area of interest has been established. The NDVI baseline was further compared to a warm and a cool year to assess vegetation conditions. Comparison results indicated better vegetation conditions in warm years and worse vegetation conditions in cool year. The different deviation patterns over the years occurred in different parks, probably as the result of regional climatic properties, vegetation types, and elevations. The implication of this study is that newly-acquired NDVI values can be compared to this established baseline, both in a temporal and spatial dimension, to allow policy maker, land managers and other sub-arctic researchers to gauge the current conditions against those of previous years.
\end{abstract}

Keywords: Sub-arctic protected ecosystems; Remote sensing; Vegetation baselines

\section{Introduction}

Vegetation ecosystems in northern high latitudes are characterized by low air and soil temperatures, a short growing season, and limited vegetation productivity [1]. These ecosystems are considered to be particularly sensitive to disturbance, defined as a "change in vegetation or the underlying substrate caused by some external factor" [2]. Among the disturbance factors, global climate change is becoming a major focus of the scientific community, after predictions based on General Circulation Models (GCMs) consistently indicate the largest relative warming for northern high latitudes [3]. Meteorological records from north-western Canada also indicate that these predicted temperature and precipitation changes might already be occurring [4]. Although it is known that vegetation ecosystems in northern high latitudes are sensitive to global changes, how they will respond remains unclear [57].

Parks Canada has conducted a monitoring program aims to understand vegetation dynamics and uses Advanced Very High Resolution Radiometer (AVHRR) data to look at the temporal variability of normalized difference vegetation index (NDVI) within its parks. This effort has focused on establishing a set of NDVI baseline to define vegetation conditions within each park. The "baseline" definition is brought from climatologists, who defined the average value of a meteorological element over 30 years as a climate baseline, and used the baseline to assess the current state against the historical averages and defined a reference for climate change. In practice, park managers can use calculated NDVI baseline to determine how unusual or how great the departures from "baseline" the up-to-date ecosystems are. Values from the current year that deviate from of the baseline range can be highlighted as not stable and possibly changing, requiring management attention.

${ }^{1}$ http://www.nass.usda.gov/research/avhrr/avhrrmnu.htm
Numerous studies have given credence to the NDVI in characterizing vegetation growth conditions as a proxy measurement [8-10]. However, more interesting in the context of this research are studies that quantify how AVHRR NDVI data can be used to determine vegetation conditions in relation to a measure of normality. In an early study, Tucker et al. [11] indicated that the image differencing technique could be used to detect inter-annual variations. The U.S. Agency for International Development's (USAID) Famine Early Warning System (FEWS) compared AVHRR NDVI time-series data to means and extremes for a special area over a specified time period [12]. Al-Bakri [13] further suggested that current NDVI can be compared with historical NDVI data to assess vegetation conditions. This type of evaluation shows how NDVI data in a year might relate to a "baseline" measure, answering the key questions brought forward by scientists and policy makers. A first successful application of NDVI baseline studies is the operational USDA (U.S. Department of Agriculture) crop and drought monitoring system ${ }^{1}$, which produces weekly reports regarding vegetation condition in crop areas by comparing current NDVI values to averaged AVHRR NDVI values from some previous period and have proved operationally important for over a decade (since 1995). Those reports have proven valuable to USDA policy officials in providing geographic location and monitoring information for vegetation condition in cropland and pasture regions throughout the growing season. In Canada, the SAGA

*Corresponding author: Yuhong He, Department of Geography, University of Toronto Mississauga, 3359 Mississauga North Road, Mississauga, ON L5L 1C6, Canada, Tel: 905-569-4679; Fax: 905-828-5273; E-mail: yuhong.he@utoronto.ca

Received May 14, 2012; Accepted May 25, 2012; Published May 30, 2012

Citation: He Y, Dixon P, Wilmshurst JF, Guo X (2012) AVHRR NDVI Baseline for Natural Vegetation Ecosystems in Northern Canadian National Parks. J Geophys Remote Sensing 1:103. doi:10.4172/2169-0049.1000103

Copyright: (c) $2012 \mathrm{He} \mathrm{Y,} \mathrm{et} \mathrm{al.} \mathrm{This} \mathrm{is} \mathrm{an} \mathrm{open-access} \mathrm{article} \mathrm{distributed} \mathrm{under}$ the terms of the Creative Commons Attribution License, which permits unrestricted use, distribution, and reproduction in any medium, provided the original author and source are credited. 
Citation: He Y, Dixon P, Wilmshurst JF, Guo X (2012) AVHRR NDVI Baseline for Natural Vegetation Ecosystems in Northern Canadian National Parks. J Geophys Remote Sensing 1:103. doi:10.4172/2169-0049.1000103

Page 2 of 5

group, Agriculture Division of Statistics Canada, develops a similar program called the Crop Condition Assessment Program², which provides weekly cropland and pasture monitoring throughout the growing season based on current and historic satellite data.

The specific objective of this study is to establish a set of NDVI baseline to quantify vegetation conditions for natural vegetation ecosystems in northern Canada National Parks using a long AVHRR NDVI image time series dataset. Since reliable continuous AVHRR data has been available from the mid 1980s, the NDVI baseline period is based on data from 1985 through 2007.

\section{Methods}

\section{Study area}

Satellite data within 12 northern national parks (Aulavik, Auyuittuq, Ivvavik, Kluane, Nahanni, Sirmilik, Torngat Mountains, Tuktut Nogait, Ukkusiksalik, Vuntut, Wapusk, and Wood Buffalo, See Figure 1) were analyzed (Quittinirpaak is excluded due to poor image quality). The national parks are a country-wide system of representative natural areas of Canadian significance and serve as an effective comparison area against which to compare development outside their boundaries. The Parks mandate includes fostering the action of unimpeded natural ecosystem processes at least at the scale of the park or ecoregion within the park. Therefore, vegetation data from the national parks would be able to represent the typical natural northern vegetation ecosystems. In this paper, we focus on deriving the NDVI annual and monthly baseline for each park for the purposes of park planning and management.

\section{The data set}

We obtained 10-day AVHRR composite images from April 1st, 1985 through October 31st, 2007. The data were processed by the second generation of the Geocoding and Compositing System (GEOCOMP-n), which was designed to produce systematic, map-compatible, multi-date composite images over large areas with reduced or no cloud content [14]. Specifically, the processing components of GEOCOMP-n included noisy line detection, calibration, geocoding, compositing, atmospheric and bidirectional reflectance corrections, identification and removal of residual clouds, and the generation of higher-level products [14]. The data set we used was comprised of 10-day, maximum-NDVI composite images with very few missing NDVI data, obtained from Manitoba Remote Sensing Center ${ }^{3}$. NDVI data processing involved four steps:

\footnotetext{
http://www26.statcan.ca/ccap/ccaphome_en.jsp
}

3http://www.gov.mb.ca/conservation/geomatics/remote_sensing/index.html

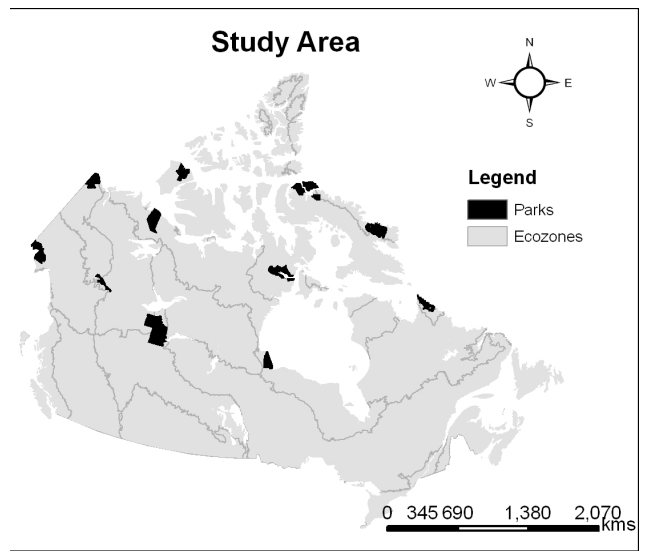

Figure 1: The selected 12 national parks in northern Canada

\begin{tabular}{|c|c|}
\hline Park & Within-park ecoregion and its dominant landcover types \\
\hline \multirow[b]{2}{*}{ Aulavik } & Ecoregion 15 - Tundra: Treeless arctic \& alpine vegetation \\
\hline & $\begin{array}{l}\text { Ecoregion } 18 \text { - Sparsely Vegetated/Barren Land: plant cover } \\
\text { general }<25 \%\end{array}$ \\
\hline Sirmilik & $\begin{array}{l}\text { Ecoregion } 5 / 22 / 24 \text { - Sparsely Vegetated/Barren Land: plant cover } \\
\text { general }<25 \%\end{array}$ \\
\hline \multirow{3}{*}{ Ivvavik } & Ecoregion 32 - Tundra: Treeless arctic \& alpine vegetation \\
\hline & $\begin{array}{l}\text { Ecoregion } 165 \text { - Tundra: treeless arctic and alpine vegetation and } \\
\text { Sparsely vegetated/Barren Land: plant cover generally }<25 \%\end{array}$ \\
\hline & Ecoregion 166- Transitional Forest: forest land $<50 \%$ of the area \\
\hline \multirow[t]{2}{*}{ Vuntut } & $\begin{array}{l}\text { Ecoregion } 165 \text { - Tundra: Treeless arctic \& alpine vegetation and } \\
\text { Sparsely vegetated/Barren Land: plant cover generally }<25 \%\end{array}$ \\
\hline & Ecoregion $166 / 167$ - Transitional Forest: forest land $<50 \%$ of area \\
\hline \multirow{3}{*}{ Tuktut Nogait } & Ecoregion 37/165 - Tundra: Treeless arctic \& alpine vegetation \\
\hline & $\begin{array}{l}\text { Ecoregion } 36 \text { - Sparsely Vegetated/Barren Land: plant cover } \\
\text { general }<25 \%\end{array}$ \\
\hline & $\begin{array}{l}\text { Ecoregion 35/166/167 - Transitional Forest: forest land }<50 \% \text { of } \\
\text { area }\end{array}$ \\
\hline \multirow[b]{2}{*}{ Auyuittuq } & Ecoregion 24/26 - Tundra: Treeless arctic \& alpine vegetation \\
\hline & $\begin{array}{l}\text { Ecoregion } 5 \text { - Sparsely Vegetated/Barren Land: plant cover } \\
\text { general }<25 \%\end{array}$ \\
\hline Ukkusiksalik & $\begin{array}{l}\text { Ecoregion } 30 \text { - Tundra: Treeless arctic \& alpine vegetation and } \\
\text { Sparsely Vegetated/Barren Land: plant cover general }<25 \%\end{array}$ \\
\hline \multirow[t]{2}{*}{ Nahanni } & $\begin{array}{l}\text { Ecoregion } 61 / 171 / 182 \text { - Coniferous Forest: canopy }>75 \% \text { conifer- } \\
\text { ous trees }\end{array}$ \\
\hline & $\begin{array}{l}\text { Ecoregion } 62 \text { - Mixed Forest: canopy } 26-75 \% \text { coniferous/broad- } \\
\text { leaf trees }\end{array}$ \\
\hline \multirow{3}{*}{ Kluane } & $\begin{array}{l}\text { Ecoregion } 173 / 184 \text { - Perennial Snow or Ice: Perennial snow fields } \\
\text { \& glaciers }\end{array}$ \\
\hline & Ecoregion 174 - Tundra: Treeless arctic \& alpine vegetation \\
\hline & $\begin{array}{l}\text { Ecoregion } 179 \text { - Coniferous Forest: canopy }>75 \% \text { coniferous trees } \\
\text { and Sparsely Vegetated/Barren Land: plant cover general }<25 \%\end{array}$ \\
\hline \multirow{3}{*}{ Wood Buffalo } & $\begin{array}{l}\text { Ecoregion 64/65/87/136/139/142- Mixed Forest: canopy } 26-75 \% \\
\text { coniferous/broadleaf trees and Coniferous Forest: canopy }>75 \% \\
\text { coniferous trees }\end{array}$ \\
\hline & Ecoregion 69 - Transitional Forest: forest land $<50 \%$ of area \\
\hline & Ecoregion 138 - Broadleaf Forest: canopy $>75 \%$ broadleaf trees \\
\hline Wapusk & $\begin{array}{l}\text { Ecoregion } 215 / 216 \text { - Transitional Forest: forest land }<50 \% \text { of area } \\
\text { and Tundra: Treeless arctic \& alpine vegetation }\end{array}$ \\
\hline
\end{tabular}

Table 1: Land cover [18] in selected national parks.

(1) checking the consistency of 1985-2007 satellite data by examining if there are any significant differences between imagery obtained from same seasons but different years, (2) extracting the NDVI data from the raw 10-day composite images for each area of interest, (3) removing outliers from the extracted data by comparing mean and median NDVI values for each area of interest. If the median value are significantly different from mean value for certain area of interest, we will consider data as outliers; (4) averaging three 10-day NDVI data for each month and averaging all twenty-one 10-day NDVI data for each year.

\section{Data analysis}

The analysis was conducted for each park to establish annual and monthly baseline, bounded by two standard deviations $(\sigma)$ of mean NDVI. Thiam [15] used the 0.5 standard deviation below mean NDVI as a measure of pixels under "threat", showing that below-baseline NDVI generally coincides with below-normal rainfall in southern Mauritania. However, Li et al. [16] felt that a 0.5 standard deviation value is too low to highlight the very sensitive areas. In this paper, two standard deviations lower and higher than the mean NDVI along time series were used to indicate the baseline range. We used the two standard deviations because statistically, values not falling within two standard deviations of the mean are seen as relatively rare events and 


\begin{tabular}{|l|l|l|l|}
\hline Park & Baseline & Year(s) & Year(s) \\
\hline & & NDVI(mean) $>2.0 \sigma$ & NDVI(mean) <2.0 $\sigma$ \\
\hline Aulavik & $0.05-0.11$ & 2007 & 1987 \\
\hline Sirmilik & $0.02-0.08$ & $2005 / 2006$ & \\
\hline Ivvavik & $0.14-0.25$ & & 1987 \\
\hline Vuntut & $0.14-0.27$ & & \\
\hline Tuktut Nogait & $0.07-0.16$ & 2004 & \\
\hline Auyuittuq & $0.00-0.06$ & $2004 / 2005$ & \\
\hline Ukkusiksalik & $0.03-0.11$ & 2005 & \\
\hline Nahanni & $0.16-0.28$ & & \\
\hline Kluane & $0.09-0.21$ & 2007 & \\
\hline Torngat & $0.01-0.13$ & 2002 & \\
\hline Wood Buffalo & $0.26-0.38$ & 2004 & \\
\hline Wapusk & $0.14-0.24$ & & \\
\hline
\end{tabular}

Table 2: Annual NDVI baseline for each park and the anomalies.

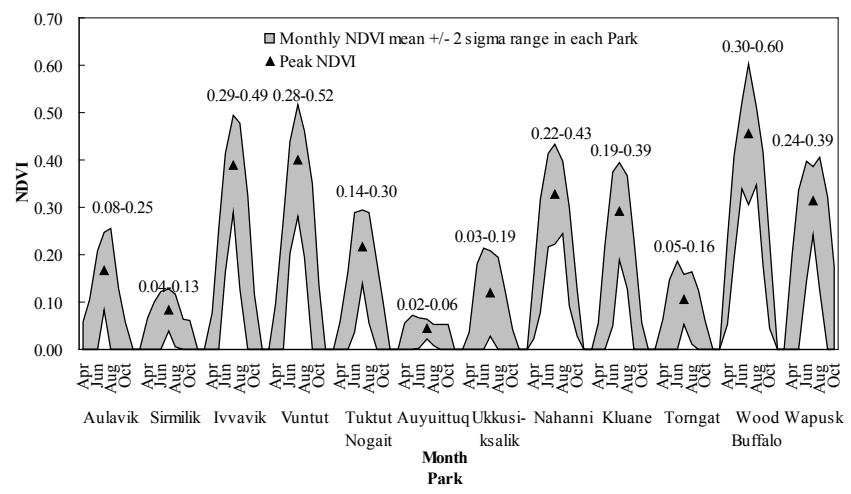

Figure 2: Monthly NDVI baseline for selected parks calculated from the 19852007 period. The peak NDVI baseline values are labeled in the figure for each park

therefore could be defined as anomalies [17]

Most parks encompass more than one ecoregion (Table 1) which has their own typical land features, climate and organisms, therefore, vegetation conditions and the responds of vegetation to changes in within-park ecoregions might be different across each park. If there is significant difference between within-park ecoregions, it is also necessary to establish NDVI baseline for each within-park ecoregion. To test this hypothesis, ANOVA analysis is used to determine if there is any significant difference among NDVI values for within-park ecoregions.

Since northern national Parks located in hardly-accessed regions of Canada, there are no available well-distributed ground truth data to evaluate large area remote sensing studies. In order to evaluate if the derived baseline values are reasonable, two methods are used: 1) the NDVI baseline data for within-park ecoregions are used to assess vegetation condition in a warm and a cool year. The 1998 year was selected as the warm year in this study since the mean temperature through 1998 growing season is relatively higher over 23 years in northern Canada. The year of 2000 was selected to be the cool year since the mean temperature in 2000 growing season is relatively lower over 23 years; and 2) the derived baseline values were used to calculate vegetation phenology data and then we compared the calculated phenology data to the observed phenology data in a volunteer ${ }^{4}$ http://plantwatch.sunsite.ualberta.ca/archive/2001canada.php phenology webpage (plantwatch ${ }^{4}$ ). Specifically, we calculated the start of growing season by fitting a logistic model to the seasonal baseline data using methods described in Ahl et al. [19]. Then, we obtained observed phonology data with associated geographical information (latitude and longitude) from plant watch webpage. The locational information of observations was overlaid to the GIS layer of parks boundary. The overlay graph indicated that three within-park ecoregion (ecoregion 64 and 136 in Wood Buffalo and ecoregion 174 in Klane) have available phenology data and the available species is aspen poplar. A total of six observations in within-Wood Buffalo ecoregion 64, three observations in Wood Buffalo ecoregion 136, and four observations in Kluane ecoregion 174 were averaged to determine the start of growing season. Although observations are very limited, the observed phenology data could still provide a meaningful comparison to phenology dates derived from remote sensing $[20,21]$.

\section{Results and Discussion}

Table 2 and Figure 2 show annual and monthly NDVI baseline for each park. Several patterns are clear. Mean NDVI has an inverse relationship with latitude. While this was not a surprise, we also detected an East-West gradient with a trend for higher NDVI in western parks. The East-West gradient is due to climatic conditions. The anomaly data show that all significant above-baseline vegetation conditions fall after 2002 in seven parks. The only below-baseline year values were found in Aulavik and Ivvavik in 1987. These anomalies might associate with variation of climate conditions and would go undetected in the absence of analysis of the data's spatial domain. The monthly time series of NDVI baseline data track seasonal growth for each park (Figure 2). On average, the peak NDVI values are in July. Similarly, NDVI baseline values are spatially heterogeneous in monthly data, higher in southern and western Parks. The highest peak NDVI baseline data are 0.30 - 0.60 showed in Wood Buffalo and lowest peak (0.02-0.06) in Auyuittuq.

ANOVA confirmed that mean annual NDVI averaged from all 23 years are significantly different among eco regions in most parks, except Aulavik and Vuntut (Table 3). Therefore, annual NDVI baseline data are also established for each within-park ecoregion (Figure 3). In addition, we can find from Figure 3 that a numbered eco region can occur within more than one park. Although it does not happen often, ecoregion 165, 166 and 167, for example, occur in Vuntut and Tuktut Nogait. The NDVI baseline values for ecoregion 165, 166 and 167 are different in Vuntut and Tuktut Nogait, indicating that it is necessary to establish baseline for each within-park ecoregion.

\begin{tabular}{|l|l|l|l|}
\hline Park & Within-park Ecoregions & Df* & P-value $^{*}$ \\
\hline Aulavik & $15 / 18$ & 1 & 0.473 \\
\hline Sirmilik & $5 / 22 / 24$ & 2 & 0.000 \\
\hline Ivvavik & $32 / 165 / 16$ & 2 & 0.019 \\
\hline Vuntut & $165 / 166 / 167$ & 2 & 0.267 \\
\hline Tuktut Nogait & $35 / 36 / 37 / 165 / 166 / 167$ & 5 & 0.000 \\
\hline Auyuittuq & $5 / 24 / 26$ & 2 & 0.000 \\
\hline Ukkusiksalik & 30 & 0 & $\mathrm{~N} / \mathrm{A}$ \\
\hline Nahanni & $61 / 62 / 171 / 182$ & 3 & 0.000 \\
\hline Kluane & $173 / 174 / 179 / 184$ & 3 & 0.000 \\
\hline Torngat & 7 & 0 & $\mathrm{~N} / \mathrm{A}$ \\
\hline Wood Buffalo & $64 / 65 / 69 / 87 / 136 / 138 / 139 / 142$ & 7 & 0.000 \\
\hline Wapusk & $215 / 216$ & 1 & 0.000 \\
\hline
\end{tabular}

* $\mathrm{df}$ (degrees of freedom) is the number of values in the final calculation that are free to vary. $P$-value is the significance of the $t$ test.

Table 3: NDVI differences among Ecoregions within parks. 


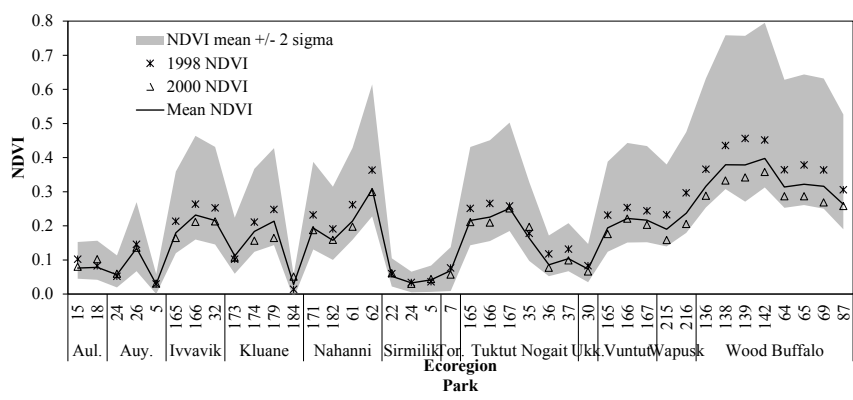

Figure 3: Annual NDVI baseline (grey area) calculated from the 1985-2007 period and annual NDVI values for a warm (1998) and a cold (2000) year for ecoregions. Along $x$ axis in this figure, Aul., Auy. Tor., and Ukk. are the abbreviation for Aulavik, Auyuittuq, Torngat, and Ukkusiksalik, respectively.

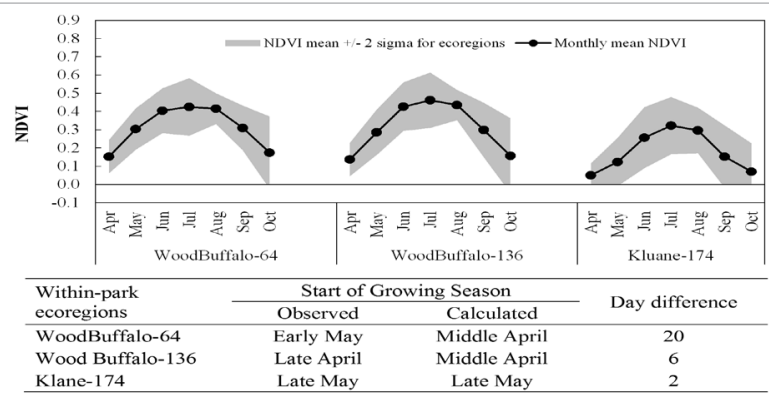

Figure 4: Top graph shows monthly NDVI baseline (grey area) and NDVI mean (black line) calculated from the 1985-2007 periods; and the bottom table shows calculated and observed start date of growing season and their differences.

The NDVI baseline data for within-park ecoregions are used to assess vegetation condition in a warm (1998) and a cool (2000) year in our series (Figure 3). Generally, NDVI values are above mean in the warm year and below mean in the cool year, but still within $+/-2$ standard deviation. The differences between the warm year NDVI average and the long-term "baseline" data or between the cold year NDVI average and the long-term "baseline" data are not consistent across ecoregions, apparently corresponding to regional climatic conditions, vegetation types, and elevations. NDVI values from Wood Buffalo National Park ecoregions depart more from their local long-term mean than do NDVI values for most other areas, whereas Auyuituq deviates less. The similar analysis can be simply applied to real-time NDVI values in each withinpark ecoregions. Although NDVI values are above mean in the warm year and below mean in the cool year for most of ecoregions, it is shown in Figure 3, the annual NDVI value from the cold year is higher than that from the warm year in some regions (e.g. ecoregion 18 in Aulavik), This may be caused by local/regional climate.

From the plantwatch observations, we found that the start of growing season for the aspen poplar was early May, late April, and late May for ecoregion 64, 136, and 174, respectively (Figure 4). The greenup estimates from baseline values were earlier than observations: about 20 days earlier in ecoregion 64, six days earlier in ecoregion 136, and two days earlier in ecoregion 174. A similar study indicated that the average green-up dates from the NDVI estimates was 43 and 45 days earlier than plantwatch observations on the boreal and transitional forested area of Canada [19]. The less differences between remote sensing estimated green up and observations might be contributed by the smaller area selected in this study in comparison with the entire boreal and transitional forested area. The 20 days differences between remote sensing estimates and observations in within-Woodbuffulo ecoregion 64 might result from combination of reduction in snow cover revealing existing understory (mosses, lichens, etc.) [19]. However, this speculation needs a well-distributed set of field measurements to confirm.

\section{Conclusions}

The NDVI baseline established in this study indicated that time series remote sensing data can be used to quantify vegetation condition for northern Canadian National Parks. The set of NDVI baseline established in this study could save substantial effort for park managers and some agencies to determine how unusual the real-time NDVI values are for specific regions within the parks. It is especially a good complement to those parks where vegetation conditions are difficult to assess. The set of NDVI baseline is also useful for many productivity modeling activities, although ground truth data are required. The NDVI baseline can be calculated using data from any sensor with both Red and NIR bands, although slight differences in wavelengths sensed might make inter-calibration necessary. It would be of considerable interest to the parks managers and academic communities if the historical NDVI data from other sensors can be used to extend and augment current AVHRR NDVI records.

\section{Acknowledgements}

Funding for this project was provided by Parks Canada.

\section{References}

1. Stow DA, Hope A, McGuire AD, Verbyla D, Gamon J, et al. (2004) Remote sensing of vegetation and land-cover change in Arctic tundra ecosystems. Remote Sensing of Environment 89: 281-308

2. Reynolds JF, Tenhunen JD (1996) Ecosystem response, resistance, resilience and recovery in Arctic landscapes: Introduction. In: JF Reynolds, J Tenhunen Landscape function and disturbance in Arctic Tundra. Springer, Heidelberg 3-18.

3. Kattenburg A, Giorgi F, Grassl H, Meehl GA, Mitchell JFB, et al. (1996) Climate models-projections of future climate. In: JT Houghton, LG Meira Filho, BA Callander, N Harris, A Kattenburg, et al. Climate change 1995 the science of climate change. The second assessment report of the IPCC: Contribution to working group 1 University Press, Cambridge, UK 285-357.

4. Serreze MC, Walsh JE, Chapin III FS, Osterkamp T, Dyurgerov M, et al (2000) Observational evidence of recent change in the northern high-latitude environment. Climatic Change 46: 159-207.

5. Mcmichael CE, Hope AS, Stow DA, Fleming JB, Vourlitis G, et al. (1999) Estimating $\mathrm{CO} 2$ exchange at two sites in Arctic tundra ecosystems during the growing season using a spectral vegetation index. International Journal of Remote Sensing 20: 683-698.

6. Muller SV, Racoviteanu AE, Walker DA (1999) Landsat MSS-derived land cover map of northern Alaska: Extrapolation methods and a comparison with photo-interpreted and AVHRR-derived maps. International Journal of Remote Sensing 20: 2921-2946.

7. Walker DA (2000) Hierarchical subdivision of Arctic tundra based on vegetation response to climate, parent material and topography. Global Change Biology 6: 19-34.

8. Cihlar J, Caromori PH, Schuepp PH, Desjardins TL, MacPherson JL (1992) Relationships between satellite-derived indices and aircraft-based $\mathrm{CO} 2$ measurements. Journal of Geophysical Research 97: 18515-18521.

9. Shippert MM, Walker DA, Auerback NA, Lewis BE (1995) Biomass and leafarea index maps derived from SPOT images for Toolik Lake and Imnavait Creek areas, Alaska. Polar Record 31: 147-154.

10. Markon CJ, Peterson KM (2002) The utility of estimating net primary productivity over Alaska using baseline AVHRR data. International Journal of Remote Sensing 23: 4571-4596.

11. Tucker CJ, Justice CO, Prince SD (1986) Monitoring the grasslands of the Sahel 1984-1985. International Journal of Remote Sensing 7: 1571-1581. 
Citation: He Y, Dixon P, Wilmshurst JF, Guo X (2012) AVHRR NDVI Baseline for Natural Vegetation Ecosystems in Northern Canadian National Parks. J Geophys Remote Sensing 1:103. doi:10.4172/2169-0049.1000103

Page 5 of 5

12. Hutchinson CF (1991) Uses of satellite data for famine early warning in subSaharan Africa. International Journal of Remote Sensing 12: 1405-1421.

13. Al-Bakri JT (2003) Application of NOAA AVHRR for monitoring vegetation conditions and biomass in Jordan. Journal of Arid Environments 54: 579-593.

14. Adair M, Cihlar J, Park B, Fedosejevs G, Erickson A, et al. (2002) GeoComp - $n$, an advanced system for generating products from coarse- and mediumresolution optical satellite data. Part 1: System characterization. Canadian. Journal of Remote Sensing 28:1-20.

15. Thiam AK (2003) The causes and spatial pattern of land degradation risk in southern mauritania using multitemporal AVHRR-NDVI imagery and field data. Land Degradation and Development 14: 133-142.

16. Li J, Lewis J, Rowland J, Tappan G, Tieszen LL (2004) Evaluation of land performance in Senegal using multi-temporal NDVI and rainfall series. Journal of Arid Environments 59: 463-480.
17. Gliner JA, Morgan GA (2000) Research Methods in Applied Settings: An Integrated Approach to Design and Analysis,Lawrence Erlbaum Associates, Mahwah, New Jersey, London.

18. (1995) Ecological Stratification Working Group, A National Ecological Framework for Canada. Agriculture and Agri-Food Canada, Canada.

19. Ahl DE, Gower ST, Burrows SN, Shabanov NV, Myneni RB, et al. (2006) Monitoring spring canopy phenology of a deciduous broadleaf forest using MODIS. Remote Sens Environ 104: 88-95.

20. EG, Hall-Beyer M (2003) Plant phenology in western Canada: Trends and links to the view from space. Environmental Monitoring and Assessment 88: 419429.

21. Peckham SD, Ahl DE, Serbin SP, Gower ST (2008) Fire-induced changes in green-up and leaf maturity of the Canadian boreal forest. Remote Sensing of Environment 112: 3594-3603. 